\title{
MODEL BLENDED LEARNING PADA DIKLAT TEKNIS SUBSTANTIF TEMATIK MADRASAH IBTIDAIYAH \\ Asih Aryani ${ }^{1}$ \\ ${ }^{1}$ Badan Litbang dan Diklat Kementerian Agama \\ 1asiharyani@yahoo.com
}

\begin{abstract}
Abstrak
Penelitian ini bertujuan untuk mengetahui respon dan peningkatan hasil belajar peserta Diklat Teknis Substantif Tematik Madrasah Ibtidaiyah dalam pembelajaran Blended Learning. Pendekatan penelitian yang digunakan kualitatif deskriptif dengan sampel 60 orang, instrumen yang digunakan observasi, dokumentasi dan angket tertutup. Proses pembelajaran dilakukan dengan lima tahapan, yaitu pembelajaran tatap muka (live event), pembelajaran mandiri (self-paced learning), kolaborasi (collaboration), penilaian (assessment), dan dukungan bahan belajar (performance support material. Hasil penelitian menunjukkan bahwa $98 \%$ peserta merasa senang dengan penerapan Blended Learning, 75\% peserta mengaku mudah memahami materi diklat yang disajikan dalam Blended Learning, dan $90 \%$ peserta merasakan bahwa model Blended Learning yang digunakan efektif. Dari hasil tes diperoleh peningkatan hasil belajar dengan selisih 13,49 (terdapat peningkatan 23,4\%), yaitu peningkatan dari nilai pre-test dengan rata-rata 57,67 menjadi post-test dengan rata-rata 71,16.
\end{abstract}

Kata kunci: Blended Learning, Respon Peserta, Hasil Belajar

\begin{abstract}
This study aims to determine the response and increase in learning outcomes of participants in the Thematic Substantive Technical training at Madrasah Ibtidaiyah in Blended Learning. The research approach used is descriptive qualitative with a sample of 60 people, the instruments used were observation, documentation and closed questionnaires. The learning process is carried out in five stages, namely: live event, self-paced learning, collaboration, assessment, and performance support material. The results show that; $98 \%$ of participants were happy with the application of Blended Learning, 75\% of participants admitted that it was easy to understand the training material presented in Blended Learning, and $90 \%$ of participants felt that the Blended Learning model used was effective. There was an increase of 13,49 (23.4\%), namely an increase from the pre-test score with an average of 57.67 to the post-test with an average of 71.16 .
\end{abstract}

Keywords: Blended Learning, Participant Responses, Learning Outcomes.

This work is licensed under a Creative Commons Attribution-NonCommercial 4.0 International License 


\section{PENDAHULUAN}

$\mathcal{M}$ unculnya teknologi terutama dalam bidang informasi dan komunikasi telah membawa manfaat yang luar biasa bagi kehidupan manusia, termasuk dalam dunia pendidikan (Usman, 2018:137). Teknologi yang berkembang dengan pesat tersebut mengharuskan adanya beberapa perubahan atau inovasi maupun transformasi dalam kegiatan pembelajaran, tak terkecuali dalam pelatihan. Penerapan teknologi dalam kegiatan pembelajaran, merupakan tuntutan pembelajaran pada abad 21, yaitu mengintegrasikan teknologi pada dunia pendidikan (Irwan, 2019: 49). Pembelajaran di masa sekarang, sudah mengarah pada pembelajaran daring, sehingga proses pembelajaran dapat dilakukan sambil mengerjakan aktivitas yang lainnya secara berkesinambungan (Sumartati dan Aryani, 2020:2).

Teknologi informasi ini telah menawarkan fasilitas serta kemudahan pada proses kegiatan pendidikan dan pelatihan (Ahmadi, 2018:314). Ketersediaan perangkat pembelajaran yang memadai, merupakan salah satu faktor penunjang proses pembelajaran yang akan berjalan dengan baik, serta merta akan turut meningkatkan mutu pendidikan (Hariyono, 2018:337). Pada kegiatan pendidikan dan pelatihan ini, widyaiswara dituntut untuk melakukan inovasi pembelajaran yang dapat mengintegrasikan pembelajaran konvensional dengan pembelajaran masa kini, diantaranya kemampuan menggunakan media teknologi sesuai tuntutan zaman (Pito, 2018: 98), yang pada ujungnya harus dapat menumbuhkan motivasi belajar bagi pesertanya, karena motivasi merupakan salah satu kekuatan mental yang mendorong seseorang untuk belajar (Nurjanah dan Aryani, 2020:224). Muwallidah, dkk. (2017:141) mengungkapkan bahwa sebuah kegiatan pembelajaran dikatakan menarik bila mampu menumbuhkan motivasi dan semangat belajar bagi peserta didik. Demikian pula, seorang pengajar dikatakan kompeten bila memiliki kemampuan mengelola program belajar-mengajar dan melaksanakan proses belajar-mengajar dengan baik (Nilasari, 2020:10). Di antara faktor penting yang menunjukkan bahwa seorang pengajar (dalam hal ini widyaiswara) itu kompeten di antaranya adalah penguasaan pola pikir keilmuan yang mendukung mata pelajaran yang diampu (Lubis, 2020:370). Widyaiswara atau pengajar yang tidak mampu memberdayakan teknologi pembelajaran melalui berbagai macam multimedia, akan tertinggal atau bahkan mungkin tidak memiliki daya saing yang secara otomatis akan menjadi hambatan dalam meningkatkan kualitas keprofesionalannya (Hamid, 2020:82).

Salah satu inovasi yang mengintegrasikan pembelajaran secara kombinasi daring dan luring adalah blended learning. Blended learning merupakan kegiatan pembelajaran yang menggabungkan atau mengombinasikan pembelajaran tatap muka (face to face) dengan media TIK, seperti komputer (online maupun offline), multimedia, kelas virtual, internet dan sebagainya (Amin, 2017:58). Pembelajaran online, jika dipersiapkan dengan tepat dan benar, dapat digunakan untuk memenuhi kebutuhan peserta dengan tingkat keahlian saat sekarang (Hanurani, 2019, 13). Kegiatan pembelajaran berbasis blended learning dilakukan diantaranya dengan menggabungkan pembelajaran tatap muka, teknologi cetak, teknologi audio, teknologi audio visual, teknologi komputer, dan teknologi m-learning (mobile learning) (Idris, 2011:61). Pembelajaran dengan model blended learning diharapkan dapat memberikan proses yang optimal dan hasil yang lebih baik (Muryanto, 2019:51).

Beberapa aktifitas yang dapat dilakukan dalam pembelajaran Blended Learning di antaranya adalah; a) melakukan interaksi melalui e-mail, chat maupun forum, b) mengerjakan tugas (assignment), c) menjawab soal-soal latihan yang disediakan di setiap topik. Keuntungan yang didapatkan dengan mengimplementasikan pembelajaran blended learning di antaranya adalah; a) memperluas jangkauan pembelajaran ataupun pelatihan; b) kemudahan dalam penggunaan dan penerapannya; c) efisiensi biaya; d) hasil yang optimal; e) menyesuaikan ragam kebutuhan 
pembelajar, dan f) meningkatkan daya tarik proses pembelajaran. (Idris, 2011:68).

Pendidikan dan pelatihan (diklat) adalah kegiatan yang bertujuan meningkatkan serta mengembangkan kompetensi pegawai di lingkungan Kementerian Agama, baik dari aspek pengetahuan, sikap maupun keterampilan (Yasri, 2018:157). Secara khusus, kegiatan pendidikan dan pelatihan, menitikberatkan pada pengembangan keterampilan pegawai untuk melakukan pekerjaan yang sedang berjalan ataupun pekerjaan yang akan dilakukannya di masa yang akan datang (Hariyono, 2018:339). Keterampilan yang dimaksud di antaranya adalah keterampilan menerapkan teknologi dalam pembelajaran. Berdasarkan penelitian sebelumnya, diklat yang diselenggarakan di Balai Diklat Keagamaan Bandung, menunjukkan bahwa kompetensi peserta diklat terhadap multimedia masih kurang (Sumartati dan Aryani, 2020:3), widyaiswara masih mendominasi pembelajaran dan belum memanfaatkan learning experience yang dimiliki peserta (Suharti, 2020:20). Hal ini menjadi tantangan tersendiri bagi lembaga maupun pengajar dalam menemukan inovasi pembelajaran guna meminimalisir kesenja-ngan tersebut.

Kegiatan pendidikan dan pelatihan (diklat) di Balai Diklat Keagamaan Bandung, di antaranya adalah adalah Diklat Teknis Substantif (DTS) Tematik Madrasah Ibtidaiyah. Sehubungan dengan tuntutan adanya peningkatan kualitas pelatihan yang diselenggarakan oleh Balai Diklat Keagamaan Bandung, maka penelitian ini difokuskan untuk mengetahui optimalisasi penggunaan model blended learning pada DTS Tematik Madrasah Ibtidaiyah. Penelitian terdahulu menunjukkan bahwa penggunaan model blended learning; a) menjadi baik secara bersama-sama dan terpisah, pada waktu yang sama maupun berbeda (Idris, 2011:67), b) menghilangkan kejenuhan dan meningkatkan hasil belajar siswa (Khairah dkk., 2017:98), c) solusi yang tepat untuk proses pembe-lajaran yang sesuai tidak hanya dengan kebutuhan pembelajaran namun juga gaya belajar peserta didik (Hima, 2014:37), $\quad$ d) meningkatnya motivasi dan hasil belajar siswa (Surya, 2019:172), dan e) mampu meng-geser prinsip pembelajaran dari teacher center menuju student center secara dinamis (Usman, 2018:145).

Berdasarkan uraian di atas, rumusan masalah dalam penelitian ini adalah: a) Bagaimana respon peserta DTS Tematik Madrasah Ibtidaiyah dalam pembelajaran blended learning? dan b) Bagaimana peningkatan hasil belajar peserta DTS Tematik Madrasah Ibtidaiyah dalam pembelajaran blended learning?

\section{METODE PENELITIAN}

Pendekatan penelitian yang digunakan adalah penelitian kualitatif, yaitu suatu prosedur penelitian yang menghasilkan data deskriptif, untuk mengetahui nilai variabel secara independen, tanpa harus membandingkan dengan variabel lainnya, serta mengungkapkan peristiwa sebagaimana adanya (Lubis, 2020:369). Kualitatif deskriptif dipilih karena dapat memberikan gambaran yang komprehensif tentang fenomena atau gejalagejala yang diteliti (Wahyuni, 2020:202). Subjek penelitian adalah peserta Diklat Teknis Substantif Tematik Madrasah Ibtidaiyah Angkatan V di Kanmenag Kota Cimahi yang berlangsung dari tanggal 28 September 2020 sampai dengan 03 Oktober 2020 sejumlah 30 orang dan Diklat Teknis Substantif Tematik Tematik Madrasah Ibtidaiyah Angkatan VI di Kanmenag Kota Bogor dari tanggal 05 sampai 10 Oktober 2020, sejumlah 30 orang. Sehingga total subjek penelitian sejumlah 60 orang.

Jenis data yang dipergunakan adalah data kualitatif dan data kuantitatif. Teknik pengumpulan data menggunakan observasi, dokumentasi dan angket tertutup yang disebar menggunakan google form, sedangkan tahapan dalam melakukan analisis data adalah mengolah data secara kualitatif dan kuantitatif dan analisis yang dilakukan adalah analisis statistik deskriptif, untuk mendapatkan presentase dan rata-rata (mean).

Strategi pembelajaran yang digunakan dengan merubah aktifitas belajar secara terbalik (strategi flipped classroom), yaitu bahan ajar dan konsep tidak diberikan di kelas, tetapi sudah disediakan sebelumnya (Rachman dkk., 2019:149) di tempat yang telah ditentukan, yaitu di Google Classroom. Sedangkan proses 
pembelajarannya menggunakan kombinasi antara bahan ajar berbasis web dan tatap muka, dengan interaksi forum diskusi lebih banyak dilakukan, yaitu sekitar 30 - 79\% (Usman, 2018:142-143).

\section{TEMUAN DAN PEMBAHASAN}

\section{Temuan}

Penelitian ini dilakukan dengan tahapan mendeskripsikan kegiatan Diklat Teknis Substantif Tematik Madrasah Ibtidaiyah yang dilaksanakan selama 6 hari, terdiri dari 60 jam pelajaran (jp). Mata Diklat inti terdiri dari: 1) Analisis SKL, KI, KD dan Indikator Pembelajaran Tematik MI (6 jp), 2) Materi Esensial Tematik MI (8 jp), 3) Teknik Penilaian Pembelajaran Tematik Terpadu (6 jp), 4) Penyusunan RPP Tematik MI (8 jp) dan 5) Praktik Pembelajaran Tematik MI (9 jp). Mata diklat penunjang diantaranya BLC (Building Learning Commitment) (4 jp) dan sisanya materi Kebijakan dll. Diklat Teknis Substantif Tematik Madrasah Ibtidaiyah ini diikuti oleh 60 orang guru Madrasah Ibtidaiyah yang semuanya PNS di berbagai Madrasah Ibtidaiyah baik Negeri (MIN) maupun swasta (MIS) di lingkungan Kanmenag Kota Cimahi dan Kanmenag Kota Bogor.

Proses pembelajaran dilakukan dengan lima tahapan, yaitu: a) tahap pertama, pembelajaran tatap muka (live event), b) tahap kedua, pembelajaran mandiri (self-paced learning), c) tahap ketiga kolaborasi (collaboration), dan d) tahap keempat penilaian (assessment), dan e) tahap kelima dukungan bahan belajar (performance support material) (Amin, 2017:62).

Tahap pertama pembelajaran dengan live event yaitu pembelajaran langsung dengan tatap muka (instructorled instruction). Pelaksanaan tatap muka dilakukan secara terpadu dalam waktu serta tempat yang sama di kelas yang sudah disediakan pihak Kanmenag Kota Cimahi maupun Kanmenag Kota Bogor, dengan menggunakan metode ceramah dan tanya jawab. Kegiatan pada tahap ini lebih difokuskan untuk menjelaskan sintak-sintak yang harus dilaksanakan oleh peserta diklat pada pembelajaran selanjutnya.
Kegiatan widyaiswara yang dilakukan sebelum memulai pembelajaran adalah; 1) widyaiswara membuat kelas virtual (google classroom), 2) memastikan semua peserta diklat memiliki akun gmail, 3) mengundang semua peserta ke dalam kelas, 4) memastikan seluruh peserta sudah terdaftar di kelas virtual, 5) widyaiswara menjelaskan semua fitur yang ada di kelas virtual dan bagaimana peserta diklat menggunakan fitur-fitur tersebut.

Pada tahap pertama pembelajaran ini, diperoleh data peserta tentang kepemilikan akun dan kebiasan menggunakannya, seperti yang disajikan pada Tabel 1 di bawah:

Tabel 1. Deskripsi Awal Peserta Diklat Teknis Substantif Tematik Madrasah Ibtidaiyah

\begin{tabular}{|c|c|c|c|c|}
\hline No & Deskripsi & Jumlah & Prosentase & Ket \\
\hline 1 & $\begin{array}{l}\text { Belum memiliki } \\
\text { akun gmail pribadi }\end{array}$ & 5 & $8,3 \%$ & $\begin{array}{l}n= \\
60\end{array}$ \\
\hline 2 & $\begin{array}{l}\text { Sudah } \\
\text { menggunakan akun } \\
\text { gmail pribadi }\end{array}$ & 55 & $91,7 \%$ & orang \\
\hline 3 & $\begin{array}{l}\text { Terbiasa } \\
\text { menggunakan } \\
\text { gmail }\end{array}$ & 40 & $67 \%$ & \\
\hline 4 & $\begin{array}{l}\text { Mengenal Google } \\
\text { Classroom }\end{array}$ & 30 & $50 \%$ & \\
\hline 5 & $\begin{array}{l}\text { Terbiasa } \\
\text { menggunakan } \\
\text { Google Classroom }\end{array}$ & 10 & $17 \%$ & \\
\hline
\end{tabular}

Sumber: Hasil Pengolahan Data

Selanjutnya peserta diklat diberikan soalsoal substansi Tematik untuk mengetahui pemahaman awal, dari 30 (tiga puluh) soal yang diberikan melalui google form, diperoleh skor paling rendah, 11 atau nilai 36,67 dan skor paling tinggi 26 atau nilai 86,67 dengan nilai rata-rata kelas 57,67.

Tahap kedua pembelajaran, pembelajaran mandiri (self-paced learning) yang dikombinasikan dengan pembelajaran konvensional. Pada tahap ini peserta diklat dimungkinkan belajar kapan saja, dimana saja dengan menggunakan rangkaian bahan belajar yang sudah disiapkan.

Pembelajaran pada hari ke-2 dan seterusnya peserta diklat sudah menggunakan Google Classroom sebagai sarana pembelajarannya, baik untuk memahami materi-materi yang disajikan pada tiap topik pembelajaran, mengisi kantong tugas yang 
sudah disediakan pada tiap topik, dan mengerjakan hal-hal lainnya yang berhubungan dengan pembelajaran.

Topik-topik yang disediakan di Google Classroom sesuai dengan mata diklat inti yang disajikan, dilengkapi dengan bahan ajar, bahan tayang, form tugas, serta kantong tugas pada masing-masing topik, yaitu Topik-1: Analisis SKL, KI, KD dan Indikator Pembelajaran Tematik Ml; Topik-2 Materi Esensial Tematik Ml; Topik-3 Teknik Penilaian Pembelajaran Tematik Terpadu; Topik-4 Penyusunan RPP Tematik MI; dan Topik-5 Praktik Pembelajaran Tematik MI.

Tahap ketiga pembelajaran, collaboration. Pada tahap ini, widyaiswara sebagai pengajar, berkolaborasi dengan peserta diklat. Penguatan materi dari widyaiswara terjadi pada tahap ini, peserta diklat sudah mempelajari sebelumnya, sehingga peserta diklat tinggal menanyakan hal-hal yang mereka kurang fahami dari materi yang sudah disediakan melalui komunikasi langsung, sehingga hal-hal yang menimbulkan miskonsepsi bisa dikurangi. Pada tahap ini pula, peserta diklat mengerjakan setiap tugas yang diberikan dengan terlebih dahulu melakukan diskusi dengan teman-teman di kelompoknya masing-masing. Setelah kegiatan diskusinya dilaksanakan dan diperoleh pemahaman yang sama, mereka meng-upload tugas masingmasing pada tempat yang sudah disediakan.

Tahap keempat pembelajaran, assessment. Pada proses ini dilakukan kegiatan pengukuran keberhasilan belajar peserta diklat. Model Blended Learning dalam kegiatan pembelajaran ini memungkinkan tes yang dilaksanakan lebih bersifat otentik (authentic assessment), karena peserta diklat menyelesaikannya dalam berbagai bentuk penilaian, baik berupa tes maupun non tes yang berbentuk project.

Pada hari terakhir (hari ke-6) diadakan post-test untuk mengetahui perkembangan hasil pembelajaran yang sudah dilalui, dengan soal-soal yang diberikan sama ketika pre-test. Hasil yang diperoleh peserta adalah skor 16 dengan nilai 53,33 dan skor 18 dengan nilai 90 dan diperoleh nilai rata-rata kelas sebesar 71,16

Selain post-test yang diberikan, peserta dipersilahkan pula untuk mengisi angket tentang respon mereka dalam pembelajaran dengan model Blended Learning ini. Respon yang diperoleh disajikan pada Tabel 2 di bawah ini:

Tabel 2. Respon Peserta Diklat Teknis Substantif Tematik Madrasah Ibtidaiyah

\begin{tabular}{llc}
\hline No & \multicolumn{1}{c}{ Aspek } & Presentase \\
\hline 1 & $\begin{array}{l}\text { Senang dengan penerapan } \\
\text { model Blended Learning }\end{array}$ & $98 \%$ \\
2 & $\begin{array}{l}\text { Mudah dalam memahami } \\
\text { materi diklat yang disajikan } \\
\text { dalam Model Blended } \\
\text { Learning }\end{array}$ & $75 \%$ \\
3 & $\begin{array}{l}\text { Model Blended Learning yang } \\
\text { digunakan efektif }\end{array}$ & $90 \%$ \\
\hline Sumber: Hasil Pengolahan Data & \multicolumn{2}{l}{$\begin{array}{l}\text { Rangkuman nilai pre-test dan post- test } \\
\text { disajikan pada Tabel 3 di bawah ini: }\end{array}$}
\end{tabular}

Tabel 3. Nilai Pre-test dan Post-test Diklat Teknis Substantif Tematik Madrasah Ibtidaiyah

\begin{tabular}{ccccc}
\hline No & Aspek & $\begin{array}{c}\text { Pre- } \\
\text { Test }\end{array}$ & $\begin{array}{c}\text { Post- } \\
\text { Test }\end{array}$ & Ket \\
\hline 1 & Nilai Terendah & 36,67 & 53,33 & $\mathrm{n}=60$ \\
2 & Nilai Terendah & 86,67 & 90 & orang \\
3 & Nilai Rata-rata & 57,67 & 71,16 & \\
Peningkatan Nilai dari Pre-test ke Post- & 13,49 \\
test & & & \\
\end{tabular}

Sumber: Hasil Pengolahan Data

Tahap kelima, dukungan bahan belajar (material performance support). Bahan belajar merupakan komponen terpenting dalam mendukung kegiatan proses pembelajaran. Pada tahap awal sebelum kegiatan pembelajaran, widyaiswara sudah menyediakan secara lengkap bahan-bahan pembelajaran, mulai dari bahan ajar, bahan tayang, soal-soal tes serta tugas-tugas yang harus diselesaikan peserta diklat sudah dipersiapkan. Penggunaan bahan-bahan ini akan menunjang kompetensi peserta diklat dalam menguasai suatu materi yang dipersyaratkan dalam sebuah pelatihan.

\section{Pembahasan}

Kegiatan pembelajaran yang telah dilakukan berdasarkan temuan di atas, dilakukan dengan lima tahapan, yaitu:

Tahap pertama, pembelajaran tatap muka (live event). Pada tahapan ini, seharusnya 
widyaiswara tinggal menjelaskan ketentuanketentuan yang akan dilaksanakan oleh peserta diklat. Tetapi, berdasarkan data pada Tabel 1 (Deskripsi Awal Peserta Diklat Teknis Substantif Tematik Madrasah Ibtidaiyah) di atas, terdapat $8,3 \%$ peserta diklat yang belum memiliki akun gmail pribadi, sekalipun jumlahnya sedikit, tetapi hal ini cukup mengganggu pada awal proses pembelajaran. Alokasi waktu yang disediakan untuk tahap awal sebagian besar digunakan untuk membantu peserta diklat membuat akun gmail pribadi tersebut. Beberapa peserta diklat yang sudah memiliki akun gmail, dilibatkan menjadi tutor sebaya bagi temannya untuk membantu membuatkan akun gmail. Beberapa peserta juga lupa dengan password yang sudah mereka miliki, sehingga banyak diantaranya yang membuat kembali akun yang baru dengan password yang wajib dicatat, agar ketika mereka membuka kembali, tidak ada kendala.

Peserta diklat yang sudah terbiasa menggunakan gmail, sebanyak 40 orang $(67 \%)$, sekalipun jumlahnya tergolong banyak, akan tetapi mereka menggunakannya baru sebatas penggunaan di media sosial (whatsapp dan facebook) dan berkirim surat elektronik (email). 50\% (30 orang) peserta diklat sudah mengenal Google Classroom, walaupun secara formal, mereka belum menggunakannya. Peserta diklat yang sudah terbiasa menggunakan Google Classroom baru 17\% (10 orang), dan rata-rata mereka berasal dari madrasah-madrasah yang sudah maju. Widyaiswara memanfaatkan peserta yang sudah terbiasa ini sebagai role-model dan memotivasi peserta diklat yang lain bahwa mereka juga akan mampu seperti itu. Kemampuan yang masih terbatas tersebut dikarenakan baru $25 \%$ guru yang menguasai teknologi pembelajaran (Hastuti, 2019:51)

Tahap kedua, pembelajaran mandiri (selfpaced learning). Pada tahapan ini, hampir seluruh peserta diklat men-download materi yang disajikan pada tiap topik. Sekalipun materi yang harus mereka pelajari bisa diakses langsung pada saat pembelajaran, tetapi kebanyakan mereka khawatir jika tidak disimpan ulang di file masing-masing, karena kemungkinan sinyal yang kurang mendukung atau kuota internetnya habis, akan menjadi kendala bagi mereka. Ketika berada di kelas, hampir tidak ada kesulitan dari peserta diklat pada tahapan ini, karena instruksi dari widyaiswara sudah mereka fahami dan mereka dapat melaksanakannya dengan baik. Hampir keseluruhan peserta menjadi asyik sendiri dengan laptopnya masing-masing, dan kelaspun hening.

Namun sebaliknya, bila sebelum pembelajaran ditanyakan tentang materi apa yang sudah dibaca di rumah, hanya satu dua yang melakukannya. Hal ini memang disinyalir bahwa tingkat literasi membaca khususnya, di tingkat sekolah/madrasah semakin kurang diminati (Zahrudin, 2019:8). Kurangnya minat dalam membaca ini tentu akan berpengaruh pada daya nalarnya. Seseorang yang memiliki kemampuan daya nalar yang baik akan mudah dalam merespon gejala yang diperoleh dari kejadian-kejadian yang dilihat maupun didengarnya secara langsung (Dais, 2019:101)

Tahap ketiga, kolaborasi (collaboration), yaitu suatu kemampuan dalam bekerja sama, mengerjakan sesuatu secara bersama-sama dengan tujuan yang sama pula (Sunbanu, dkk. 2019:2039), mengandung unsur ketergantungan yang positif dan mengarah pada tujuan bersama yang hendak dicapai dalam suatu kelompok (Dewi, dkk., 2020:59).

Pada tahapan ini, kegiatan pembelajaran menjadi penuh kehangatan, berbanding terbalik dengan tahap kedua, karena hampir 100\% mereka berinteraksi langsung dengan peserta yang lainnya ketika mendiskusikan materimateri yang sudah mereka baca, tetapi belum difahami. Pada tahapan ini peserta diklat dibagi menjadi kelompok dengan maksimum anggota sebanyak lima orang. Seperti pada tahapan kedua, tahap kolaborasi ini juga hampir tidak ada kendala. Semua kegiatan berlangsung dengan aktif, komunikasi multi arah: antar peserta dengan peserta ataupun antar peserta dengan widyaiswara terjalin dengan baik.

Kolaborasi yang baik, terjadi bila lima indikator kolaborasi terjadi dalam sebuah kegiatan pembelajaran, yaitu; a) berkontribusi secara aktif, b) bekerja secara produktif, c) menunjukkan fleksibilitas dan kompromi, d) mengelola kegiatan dengan baik, dan e) menunjukkan tanggung jawab, dan sikap menghargai (Rahmawati, dkk., 2019:433). 
Tahap keempat, penilaian (assessment). Penilaian, sebagaimana yang biasa terjadi pada peserta didik di sekolah/madrasah, maka pada peserta diklat juga terjadi hal yang sama. Pada proses ini dilakukan kegiatan pengukuran keberhasilan belajar peserta diklat. Aktifitas peserta dengan model Blended Learning ini, dalam kegiatan pembelajarannya dimungkinkan menggunakan penilaian yang bersifat otentik (authentic assessment), yaitu proses pengumpulan informasi tentang perkembangan serta pencapaian pembelajaran yang dilakukan oleh peserta melalui berbagai teknik yang mampu mengungkapkan, membuktikan bahwa tujuan pembelajaran sudah tercapai (Salamah, 2018:281).

Penilaian yang dilakukan pada saat pembelajaran ini menggunakan tes dan non tes. Penilaian non-tes yang dilaksanakan berbasis project, yaitu penilaian hasil kerja yang diberikan untuk mengontrol proses dengan memanfaatkan dan menggunakan bahan untuk menghasilkan sesuatu, kerja praktik atau kualitas estetis dari sesuatu yang mereka produksi (Salamah, 2018:279).

Hasil akhir yang diberikan pada peserta diklat, berupa post-test dalam bentuk googleform, diperoleh nilai seperti pada table 3 (Nilai Pre-test dan Post-test Diklat Teknis Substantif Tematik Madrasah Ibtidaiyah), diperoleh peningkatan hasil dengan selisih 13,49 , yaitu peningkatan dari nilai pre-test dengan rata-rata 57,67 menjadi post-test dengan rata-rata 71,16 (peningkatan sebanyak $23,4 \%)$.

Tahap kelima, dukungan bahan belajar (performance support material). Sebuah kegiatan pembelajaran tidak akan optimal tanpa dukungan bahan ajar. Bahan ajar (instructional materials) secara garis besar terdiri dari pengetahuan (knowledge), keterampilan (skill), dan sikap (attitude) yang harus dipelajari seorang pembelajar dalam memenuhi standar kompetensi yang telah ditentukan (Aisyah, dkk., 2020:63). Pemanfaatan bahan ajar semestinya menjadi bahan kajian bagi pengajar/widyaiswara, bagaimana cara yang terbaik untuk menyampaikannya, agar menjadi mudah bagi peserta dalam mempelajarinya, karena hal ini sering menjadi permasalahan, bahan ajar terlalu luas, urutan penyajian yang kurang tepat serta jenis materi yang kurang sesuai dengan kompetensi yang ingin dicapai.

Bahan ajar yang disajikan dalam pembelajaran ini diupload oleh widyaiswara sebelum kegiatan diklat dimulai. Bahan ajar yang disajikan ini, menggunakan bahan ajar berbasis multimedia, ada beberapa yang sudah disediakan dalam bentuk pdf, ada pula yang disediakan dalam bentuk link-nya saja, dari sumber yang dibuat selain widyaiswara. Hal ini sejalan dengan hasil penelitian Hartini dan Situmorang (2015:227) menyatakan bahwa penggunaan bahan ajar melalui multimedia $(88,91 \%)$ lebih efektif dibandingkan dengan bahan ajar yang menggunakan modul $(82,03 \%)$.

Berdasarkan respon peserta diklat tentang pembelajaran Blended Learning ini, diperoleh data seperti pada Tabel 2 (Respon Peserta Diklat Teknis Substantif Tematik Madrasah Ibtidaiyah), pada umumnya peserta merasa senang dengan penerapan model Blended Learning $(98 \%)$, hal ini dikarenakan peserta merasa antusias, dianggap sebagai hal yang baru dan mereka bertekad berusaha untuk mengimplementasikannya di madrasah masingmasing, apalagi dengan situasi sekarang yang lagi masa Pandemic Covid-19, guru dituntut untuk merubah kebiasaan belajar mengajarnya, dari model yang konvensional ke model yang dapat memfasilitasi siswa belajar di mana saja dan kapan saja. Hasil penelitian ini sejalan dengan Manggabarani (2016:63) dan Surya (2019:271) bahwa ada pengaruh model pembelajaran Blended Learning terhadap motivasi dan hasil belajar peserta.

Penggunaan bahan ajar pada diklat ini mendapat respon yang baik pula dari peserta diklat (mudah dalam memahami materi diklat yang disajikan dalam Model Blended Learning, sebanyak $75 \%$ ), hal ini sejalan dengan hasil penelitian Irwan dkk (2019:56) bahwa desain model pembelajaran dapat dirancang untuk memenuhi kebutuhan pengajar dan pembelajar, agar cara belajarnya bervariasi, menanggulangi kekurangan waktu dalam penyampaian materi ajar dengan memanfaatkan fasilitas yang tersedia.

Respon yang baik juga dari peserta sebanyak 90\%, yaitu Model Blended Learning 
yang digunakan efektif. Hal ini sejalan dengan hasil penelitian dari Usman (2018:136) bahwa penerapan model Blended Learning ini mampu meningkatkan mutualitas dan kualitas pembelajaran, menunjukkan perbedaan yang lebih baik dari sisi motivasi, minat, maupun hasil belajar.

\section{PENUTUP}

\section{Simpulan}

Berdasarkan temuan dan pembahasan yang telah diuraikan di atas, maka diperoleh:

a) Respon peserta Diklat Teknis Substantif Tematik Madrasah Ibtidaiyah dalam pembelajaran Blended Learning, yaitu; sebayak $98 \%$ peserta merasa senang dengan penerapan Blended Learning, sebanyak $75 \%$ peserta mengaku mudah memahami materi diklat yang disajikan dalam Blended Learning, dan 90\% peserta merasakan bahwa model Blended Learning yang digunakan efektif.

b) Peningkatan hasil belajar peserta Diklat Teknis Substantif Tematik Madrasah Ibtidaiyah dalam pembelajaran Blended Learning, diperoleh peningkatan hasil dengan selisih 13,49 (terdapat peningkatan sebanyak $23,4 \%$ ), yaitu peningkatan dari nilai pre-test dengan rata-rata 57,67 menjadi post-test dengan rata-rata 71,16

\section{Rekomendasi}

Dari simpulan di atas, maka direkomendasikan:

a) Bagi peneliti selanjutnya untuk mengembangkan model Blended Learning ini dengan persiapan yang lebih baik lagi, agar respon peserta semakin meningkat.

b) Bagi Lembaga, dalam hal ini Balai Diklat Keagamaan Bandung, untuk mengembangkan model Blended Learning ini secara holistik, baik dari sisi penyelenggaraan, pelaksanaan pembelajaran, penyediaan sarana dan prasarana terutama jaringan internet yang memadai, agar peningkatan hasil belajar sesuai kompetensi yang dipersyaratkan. 


\section{DAFTAR PUSTAKA}

Abdullah, Walib. (2018). Model blended Learning dalam Meningkatkan Efektifitas Pembelajaran. FIKROTUNA: Jurnal Pendidikan dan Manajemen Islam Volume 7, Nomor 1, Juli 2018; p-ISSN 24422401; e-ISSN 2477-5622

Ahmadi, Agus. (2018). Faktor Kesiapan Widyaiswara dalam e-Learning. Inovasi, Jurnal Diklat Keagamaan Volume 12 No 4, Oktober - Desember 2018. ISSN 1978 - 4953

Aisyah, dkk. (2020). Bahan Ajar sebagai Bagian dalam Kajian Problematika Pembelajaran Bahasa Indonesia. Jurnal Salaka Volume 2 Nomor 1 Tahun 2020 HIm. 62-65

Amin, Ahmad Kholikul. (2017). Kajian Konseptual Model Pembelajaran Blended Learning berbasis Web untuk Meningkatkan Hasil Belajar dan Motivasi Belajar. JURNAL PENDIDIKAN EDUTAMA, Vol 4, No2 Juli 2017

Banggur, dkk. (2016). Pengembangan Pembelajaran Berbasis Blended Learning Pada Mata Pelajaran Etimologi Multimedia. Jurnal Teknologi Pendidikan Vol. 20, No. 2, Agustus 2018.

Dais, Mohamad. (2019). Membaca Memotivasi dalam Berkarya. Lembaga Pendidikan Sukarno Pressindo. Semarang

Dewi, dkk. (2020). Profil Keterampilan Kolaborasi Mahasiswa pada Rumpun Pendidikan MIPA. Pedagogia Jurnal IImu Pendidikan 18 (01) (2020) 57 -72.

Hanurani, Hikmawati. (2019). Peningkatan Kompetensi Profesional Guru Biologi Madrasah Aliyah melalui Pembelajaran Jarak Jauh. Tatar Pasundan Jurnal Diklat Keagamaan ISSN 2085-4005 Volume XIII Nomor 35 Tahun 2019: 10-22

Hamid, Amrin. (2020). Peran Media Pembelajaran dalam Meningkatkan Minat Belajar Peserta Diklat. Jurnal IImiah BARUGA, Volume IX Nomor 3/ Maret 2020. ISSN 1978 - 2233

Hariyono, Rudi. (2018). Optimalisasi Pembelajaran Substantif IPS Berbantuan Media Pembelajaran Sederhana pada Diklat Teknis Substantif Guru IPS MTs. Inovasi, Jurnal Diklat Keagamaan Volume 12 No 4, Oktober - Desember 2018. ISSN 1978 - 4953

Hartini dan Situmorang. (2015). Pengembangan Bahan Ajar Berbasis Multimedia dengan Strategi Pembelajaran Kooperatif (Cooperative Learning) pada mata Diklat Analisis Mikrobiologi di SMK. Jurnal Teknologi Informasi \& Komunikasi dalam Pendidikan, Vol. 2, No. 2, Desember 2015, pISSn: 2355-4983; e-ISSN: 2407-7488

Hastuti, Puji. (2019). Guru Kreatif dengan Literasi. Lembaga Pendidikan Sukarno Pressindo. Semarang

Hima, Lina Rihatul. (2014). Pengaruh Pembelajaran Bauran (Blended Learning) terhadap Motivasi Siswa pada Materi Relasi dan Fungsi. Jurnal IImiah Pendidikan Matematika Volume 2 Nomor 1 P-ISSN: 2502-7638; E-ISSN: 2502-8391

Idris, Husni. (2011). Pembelajaran Model Blended Learning. Jurnal Iqra' Vol.5. No.1, Januari - Juni 2011 Irwan, dkk. (2019). Desain Model Pembelajaran Blended Learning pada Perkuliahan Hubungan Internasional. REFLEKSI EDUKATIKA : Jurnal IImiah Kependidikan Volume 10 Nomor 1 Desember 2019 ISSN: 2087-9385 (print) dan 2528-696X (online).

\section{http://jurnal.umk.ac.id/index.php/RE}

Khoirah, dkk. (2017). Pengaruh Model Pembelajaran Blended Learning dan Motivasi Belajar Terhadap Hasil Belajar Siswa. Jurnal Penelitian Ilmu Pendidikan Volume 10 Nomor 2, September 2017.

Lubis, Saidan. (2020). Penerapan Discovery Learning dalam Mewujudkan Pembelajaran Efektif (Kajian Pelatihan Guru Mata Pelajaran Ushul Fikih Madrasah Aliyah Kejuruan di Balai Diklat Keagamaan Padang). Andragogi: Jurnal Diklat Teknis Pendidikan dan Keagamaan Vol. 8, No. 1, Juni 2020

Manggabarani, dkk. (2016). Pengaruh Model Pembelajaran Blended Learning terhadap Motivasi dan Hasil Belajar Siswa Kelas X SMA Negeri 1 Pitumpanua Kab. Wajo (Studi Pada Materi Pokok Sistem Periodik Unsur). Jurnal Chemica Vo/. 17 Nomor 2 Desember 2016, 83 - 93.

Muryanto, Urip. (2019). Hasil Belajar Peserta Diklat Teknis Substantif Media Pembelajaran Berbasis Multimedia (Studi di Kantor Kementerian Agama Kota Bekasi). Tatar Pasundan, Jurnal Balai Diklat Keagamaan Bandung, Volume XIII Nomor 1 Tahun 2019. ISSN 2085 - 4005. 
Muwallidah, dkk. (2017). Pengembangan Model Pembelajaran Blended Learning pada Mata Pelajaran Ekonomi KD Sistem dan Alat Pembayaran Kelas X IPS di SMAN 2 Jember Tahun Pelajaran 2016/2017. Jurnal Pendidikan Ekonomi: Jurnal IImiah IImu Pendidikan, IImu Ekonomi, dan IImu Sosial ISSN 1907-9990 | E-ISSN 2548-7175 | Volume 11 Nomor 2 (2017) D0I: 10.19184/jpe.v11i2.6461

Nilasari, Kurnia Eva. (2020). Efektifitas Pelatihan Model-model Pembelajaran terhadap Efikasi Diri dan Kompetensi Pedagogik Guru. Journal of Education, Administration, Training, and Religion Vol. 1 No. 1 Tahun 2020 D0l: http://dx.doi.org/10.38075/ien.v1i1.9

Nurjanah dan Aryani. (2020). Meningkatkan Hasil dan Motivasi Belajar Peserta Didik melalui Model Problem Based Learning. Tatar Pasundan Jurnal Diklat Keagamaan Volume 14 Nomor 2 Tahun 2020. pISSN 2085 - 4005, elSSN 2721 - 2866

Pito, Abdul Haris. (2018). Media Pembelajaran dalam Perspektif Al-Qur'an. Andragogi, Jurnal Diklat Teknis. Volume VI No. 2 Desember 2018. ISSN 0216 - 0333

Priono, dkk. (2018). Pengaruh Penerapan Model Pembelajaran Blended Learning terhadap Hasil Belajar Menggambar 2 Dimensi Menggunakan Computer Aided Desain. Journal of Mechanical Engineering Education, Vol. 5, No. 2, Desember 2018

Rachman, dkk. (2019). Penerapan Model Blended Learning dalam Peningkatan Hasil Belajar Menggambar Objek 2 Dimensi. Journal of Mechanical Engineering Education, Vol. 6, No. 2, Desember 2019

Rahmawati, dkk. (2019). Analisis Keterampilan Bekolaborasi Siswa SMA pada Pembelajaran Berbasis Proyek Daur Ulang Minyak Jelantah. Jurnal Pendidikan dan Pembelajaran Kimia Universitas Lampung. Vol. 8 No. 2 (2019)

Salamah, Umi. (2018). Penjaminan Mutu Penilaian Pendidikan. Evaluasi Vol. 2, No. 1. Maret 2018. PISSN 2580 - 3387. E-ISSN 2615 - 2886

Sudarman. (2014). Pengaruh Strategi Pembelajaran Blended Learning terhadap Perolehan Belajar Konsep dan Prosedur pada Mahasiswa yang memiliki Self-Regulated Learning Berbeda. Jurnal pendidikan dan Pembelajaran, Volume 21 Nomor 1, April 2014.

Suharti, Atiyah. (2020). Peningkatan Kompetensi Peserta Pelatihan melalui Penggunaan Pembelajaran Berbasis Pemecahan Masalah. Tatar Pasundan. Jurnal Diklat Keagamaan pISSN 2085-4005; eISSN 2721-2866 Volume XIV Nomor 1 Tahun 2020: 19-26

Sumartati dan Aryani. (2020). Implementasi Pembelajaran Berbasis Multimedia bagi Peserta Diklat Teknis Substantif Media Pembelajaran di Kanmenag Kota Bekasi. Jurnal IImiah BARUGA, Volume IX Nomor 3/Maret 2020. ISSN 1978 - 2233

Sunbanu, dkk. (2019). Peningkatan Keterampilan Kolaborasi Siswa Menggunakan Model Kooperatif Two Stay Two Stray di Sekolah Dasar. Jurnal Basicedu Vol 3 No 4 November Tahun 2019 p-ISSN 25803735 e-ISSN 2580-1147

Surya, Bambang Joko. (2019). Pengaruh Metode Blended Learning Berbasis Web dan Motivasi terhadap Hasil Belajar Biologi pada Pokok Bahasan Klasifikasi Makhluk Hidup di Kelas X SMA Negeri 1 Secanggang Langkat. JURNAL BIOLOKUS Vol.2 (1). Januari - Juni 2019. ISSN-E: 2621-7538. ISSN-P: 2621 - 3702

Sjukur, Sulihin. (2012). Pengaruh Blended Learning terhadap Motivasi Belajar dan hasil Belajar Siswa Tingkat SMK. Jurnal Pendidikan Vokasi, Vol 2, Nomor 3, November 2012

Usman. (2018). Komunikasi Pendidikan Berbasis Blended Learning dalam Membentuk Kemandirian Belajar. Jurnalisa Vol 04 Nomor 1/Mei 2018

Wahyuni, Leni Sri. (2020). Membangun Kompetensi Abad 21 melalui Metode Constructive Controversy pada Pembelajaran Bahasa Inggris. Tatar Pasundan Jurnal Diklat Keagamaan PISSN 2085-4005; EISSN 2721-2866 Volume XIV Nomor 2 Tahun 2020: 199-208

Yasri. (2018). Dampak Program Pelatihan Teknis Fungsional Guru terhadap Sikap Sosial Guru Madrasah. Andragogi, Jurnal Diklat Teknis. Volume VI No. 2 Desember 2018. ISSN 0216 - 0333

Zahrudin, Ma'mun. (2019). Membangun Kualitas Bangsa dengan Budaya Literasi. Lembaga Pendidikan Sukarno Pressindo. Semarang 